\title{
Theatre: Stability and Dynamics
}

\author{
Luule Epner, Anneli Saro
}

In 2006, Estonian professional theatre celebrated its $100^{\text {th }}$ anniversary. On a national level, the year was officially designated as the Year of Estonian Theatre. To celebrate this occasion, the Union of Estonian Theatre Researchers and the Department of Theatre Research and Literary Theory of the University of Tartu organized an international conference titled "Theatre: Stability and Dynamics" in Tallinn on 8 and 9 December. The articles in this volume of Methis are elaborations of selected papers presented at this conference. The issue closes with three book reviews.

Despite the fact that the first book in the Estonian language was published in 1525, and the University of Tartu was founded in 1632, two motifs have been widely disseminated in Estonian culture and the unconscious minds of Estonians: peripherality and belatedness. The first of these derives from the fact that for long centuries, Estonia has been a peripheral region, at the outskirts, so to speak, of German culture, then a border zone for the Russian Empire, the Soviet Union, and finally, the European Union. This fact might also be interpreted positively - according to Juri Lotman, the most active communication and the receiving of new information takes place at borders (Lotman 1999). However, Estonians have mostly positioned themselves with respect to their distance from major metropolises. The sense of cultural belatedness is also largely due to geopolitical location.

Because of poor economic and complicated political conditions, Estonians gained access to education and arts relatively late - approximately in the middle of the $19^{\text {th }}$ century. All the way to the present, the feeling of backwardness has never left our consciousness, and is with us still; constantly urging upon us an imperative for economical and cultural acceleration. Paradoxically, however, and because of several political and cultural ruptures, traditions and stability have also been highly valued in Estonia. Thus Estonian consciousness and identity is torn between force fields of dynamics and stability. What applies to Estonians, probably applies to many other people, nations, and cultures as well.

If we take a closer look at the two concepts that frame the theme of the issue, two observations should be emphasized: first, these terms are not antonyms; they do not form a clear binary opposition or dichotomy. Second, both terms have positive connotations, which cannot be said of their opposites - lability and statics. Stability, which derives from the Latin stabilis (unshakeable, firm) means a system or a phenomenon in a state of energetic endurance, and demonstrates the functional competence of feedback systems. The condition characterized by lability (fluctuation, lack of persistence) should be temporary, after which the system should achieve a new state of balance - temporary stability. For people participating in a system, stability imparts a sense of security, which is apparently 
an important emotional need for us all. However, dynamics (Greek dynamikos, meaning pertaining to force) is just as important and valuable; it refers to change in a system or phenomenon, a course of development. When we speak of the dynamism of processes, we are referring to their forceful, fast-paced development, resulting in noticeable changes. Its opposite, statics, connotes immoveability, lack of change, a condition in which change is generally tolerated for only short periods and is judged to be a negative factor. Stability is not equivalent to statics, nor dynamics to instability! Thanks to their positive meaning and content, stability and dynamics seem to be good covering terms, enabling the analysis of a variety of connections at many levels both in theatre history and performance analysis.

The topic of the journal - Theatre: Stability and Dynamics - is open to different approaches and questions, which together might be applied to heterogeneous empirical material. The organizers of the conference, who are also editors of the volume, proposed five possible approaches to the topic: phenomenological, aesthetic, ideological, organizational and historiographic.

Phenomenological approach. Do performance arts, which have no stable material carrier, have any special features? How do the changing nature of theatrical playing and individual performance influence the core of role and production? How is it possible to ensure aesthetic stability and quality in theatre?

Aesthetic approach. How have the two antagonistic forces of tradition and innovation moulded theatre arts and single productions in different historical periods? How have the expectations and tastes of audiences influenced theatrical practice?

Organisational approach. How and why do theatre institutions or systems change? How do different theatre institutions or systems provide stability and dynamics, and what kind of influence do they have on art?

Ideological approach. How does theatre reflect (or ignore) political, social, and cultural changes? What kinds of phenomena tend to be stable and what kinds of phenomena are open to more liberal interpretations in theatrical representations?

Historiographic approach. How is stability and dynamics of theatre reflected in theatre histories? How and why have these two categories been valued during different periods and by different institutions?

Without a doubt, the same regularities apply to theatre history as to other historical processes, those that historians notice when they order the events of the past into coherent narratives. Granted, historical research cannot be reduced to narratives: besides telling stories, the task of the historian is also to explain and interpret the past. However, one cannot underestimate the importance of narrative as a cognitive scheme for understanding history, and as a type of discourse for presenting historical knowledge (cf. Väljataga 2008: 687). Every narrative or representation of processes transpiring over time is made up of narratable events; an event always contains a change or shift of some kind, highlighting a dynamic source. It is change which differentiates 
an event (which can be narrated) from a fact (which it is sufficient to be stated). When making connections and devising sequences of events, that is, when constructing a narrative, a theatre historian is usually interested in what has changed, what developments have taken place, and for what reasons. If we look at theatre history through the prism of change, a range of categories and concepts come into play which are helpful for modelling historical processes: progress, renewal, revolution, breakthrough, crisis, cyclicality, rupture, transformation, etc. What type of history gets written depends on which models are favoured and valued. "The processes of change take their meaning, therefore, from the classification system that is embedded within (and formulated by) the idea of change we use to order history." (Postlewait 1991: 176.) At the same time, the conceptualization of history on the basis of change (as a dynamic process) has tilted theatre research in the direction of privileging the avant-garde and the innovative at the expense of "ordinary" theatrical forms. Alan Woods draws attention to the fact that the tacit assumption behind avant-garde-focused histories of the theatre is the equation of historical change/development with progress, that is with change for the better, as well as the belief that progress is unavoidable (cf. Woods 1989). The modernist longing for the new seems to have had a strong influence on the thinking and value criteria of theatre researchers in the postmodern age. As a counterbalance, we have recently seen a turn on the part of theatre researchers toward popular, "ordinary" forms of the theatre, as well as a quest for alternative models of development. (On the meta-level, historians' interest in the stable genres of the theatre has been spurred by scholarly discourse, with its ongoing pressure to generate new knowledge.) For example, the authors of the recently published "Theatre Histories: An Introduction" claim that they are organizing the historical narrative in a new way, relating the histories of performance and theatre to the key developments in modes of human communication (Zarrilli, McConachie et al. 2006: XVII). Thus there is a place in the book for theatres of popular entertainment, as well as sentimental drama and melodrama of the $18^{\text {th }}-19^{\text {th }}$ centuries, which usually does not draw the attention of theatre historians.

It can be ventured, then, that, in theatre history research, the pendulum has swung between the poles of innovation and tradition, or, in other words, dynamics and stability. In the broader, cultural semiotic perspective, stability and dynamics are categories that have "contaminated" each other, rather than being sharply differentiated. Just as there are no absolutely immutable structures in human culture, there is no dynamics in the absolute sense, at least not in a longrange perspective. The relationship between statics and dynamics, or the question of how a developing system preserves its identity is thought to be one of the most fundamental questions of semiotic systems (cf. Lotman 2001: 9). Here explosive changes occur side by side with slow processes, maintaining a complicated dialogue with stabilizing mechanisms internal to the culture, in order to guarantee the continuity of developmental processes (ibid, 17); continuity is as important and necessary to the viability of cultural systems as are change and innovation. According to such a dialectical model, stability and dynamism of historical processes are 
connected among themselves, indeed as inseparable characteristics.

While in theatre history the concepts of stability and dynamics easily acquire concrete content and meaning, they cannot be so readily applied in phenomenological approaches to theatre arts. Yet on closer examination it becomes apparent that the pair of concepts describes crucial aspects of theatre ontology. The characteristics considered specific to the theatre is the uniqueness and ephemerality of the work of theatre art. In a monograph devoted to the ontological status of works of art, L'Oeuvre de l'art: immanence et transcendance (1994), Gérard Genette treats performances as temporal processes, of which one aspect of essential identity is duration (durée); a performance can be experienced only once, because by its very nature it is irreversible and incapable of repetition (Genette 1994: 73). The concept of dynamics connects with the processuality of theatre and its consequent ephemerality.

Indeed, theatre art is readily defined through its ephemerality, evanescence, unrepeatability: theatre has its effect only "here and now"; it is "written on the wind", etc. Thus theatre's unique vitality is emphasized and valued in opposition to those arts which are mechanically reproducible. Evanescence and uniqueness are put on a pedestal as theatre's core values. Yet in parallel to the celebration of evanescence there exists the desire to repeat and preserve the theatrical performance, thus saving it from falling into oblivion. In such a case ephemerality becomes a negative phenomenon, which should be stood against as far as possible. Procedures of conservation that try to make performances lasting in some respect are connected with the concept of stability, despite the fact that they produce only "traces" (texts, photos, video recordings), and that the resulting imaginary representation of a past performance is always approximate and partial.

From another angle, describing the theatre as an essentially "dynamic" and ephemeral art is one-sided. Theatre is just as much an art of repetition, memorization and remembering. Although each performance is unrepeatable, it is usually based on a firm structure or performance score, which is repeated with variations through tens and hundreds of performances. Indeed, Genette acknowledges that while the theatre performance operates in an autographical regime (one that emphasizes authenticity and uniqueness), through preservation and repetition it crosses over into an allographic regime (one that permits copying and replication) (Genette 1994: 84)1. Thus in the case of the theatrical work of art one has to do with a complicated and ambivalent case. However, if we emphasize in addition the strong ties between theatre and collective cultural memory, and theatre as one of its depositories, then theatre can also be defined in contradistinction to the definition proposed before, as a cultural activity connected to memory, the nature of which is repetition. Theatre is by nature a memory machine, as Marvin Carlson has claimed (2001: 11). (According to

1 The distinction between allographic and autographical regimes is borrowed from Nelson Goodman. In the first case, the copies of a work must be regarded as exempla (but not as counterfeits); in the second case the determining characteristic of the work is its uniqueness, that is, what is emphasized is the question of authenticity. 
Carlson, reiteration in theatre proceeds on at least four levels: spatial (theatre buildings), dramaturgic (plays), material (primarily actors) and the level of reception.) Therefore in the realm of the ontology of theatre, we see in operation a dialectic of persistence and change, of unrepeatability and reiteration.

Finally, let us recall that in the last decades a paradigm shift has occurred in performance analysis from conceptualization as an artefact (art object, text) to comprehension as a theatrical event, and this has been accompanied by a reevaluation and renewal of methods of analysis. The concept of theatrical event foregrounds dynamism and places the performance into the framework of human communication and interaction. (It is noteworthy that the subtitle of Willmar Sauter's monograph "The Theatrical Event" (2000) is "Dynamics of Performance and Perception"; cf. also Sauter's article in this collection.) Of course this shift is part of a more general paradigm shift in cultural studies, which has begun to be referred to as the "performative turn". Emphasizing the eventfulness of the theatre performance brings into focus the spectators, since an event can only take place between performers and viewers, with the participation of both. This in turn favours phenomenological and reception-oriented approaches to the theatrical performance, while the formerly dominant semiotic approach has come under criticism.

In the area of reception research Erika Fischer-Lichte's studies of the nature of aesthetic experience are worthy of special mention. Fischer-Lichte claims that in today's theatre aesthetic experience manifests itself as liminal experience, the main characteristic of which is instability: the destabilization of the self-perception and world-perception of the receiving subject, with attendant changes in corporeal state (Fischer-Lichte 2001: 355). Thus we can see that the latest developments in performance analysis strongly foreground dynamic aspects. The meanings of the performance are born in dynamic performative processes, which influence and change the meaning systems of the receiver.

Although one can encounter diverse emphases in contemporary theatre research, the general tendency seems to be the valorization of dynamism and change. However, this does not take place (or at least should not take place) with the denial or underestimation of stability. Rather, stable states and dynamic processes belong to the same continuum instead of being opposed to one another. The retreat of linear and/or dichotomous models of description from such models which describe processes and phenomena through spectra or continua can however be seen as the overall epistemological framework of theatre research today.

In his article "Theatre - a Building, a Company, an Art Form: Terminology versus Reality" Willmar Sauter takes a look at the paradigmatic changes in the conceptualisation of theatre and in the meaning of the term theatre, respectively. He shows, how a term, historically used only rarely to describe an art form, but rather a certain building, underwent deep transformations in the $19^{\text {th }}$ and $20^{\text {th }}$ centuries. Sauter exemplifies these changes by analysing 
August Strindberg's and Max Reinhardt's ideas about theatre. These different concepts of theatre have influenced theatre studies in many ways. Strindberg's influential but hierarchical model of theatre as an art form privileges text and, to some extent, stage directing, but clearly underestimates the role of immediate human communication in the theatre. Thus, Sauter proposes the concept of theatrical event, which emphasises the interaction and communication between performers and spectators. The dynamic concept of theatre brings to the fore the unreliable nature of words, one of the main vehicles of human communication, but also the diversity of artistic and non-artistic phenomena it covers.

In his article "Hamlet's Being and Not-Being - Dynamics of the Aesthetic Object of Theatrical Performance", Mariusz Bartosiak makes use of a phenomenological approach to highlight different kinds of instabilities in a theatrical performance: in performing a character, within the fictional world of performance, and in reception, all of which can be exemplified by the most classical theatrical character, Hamlet. Bartosiak states that the dynamics of theatrical art is connected with ambiguities in perception and understanding of the aesthetic object, and that instability depends both on the actor and the spectator. He conceives instability on the basis of phenomenology and concludes that instability is fundamental for theatrical art, and is related to human body as a main carrier of artistic information. In this context, one might wonder how it is possible to communicate about the same artistic object (a production), when both its presentations (performances) and receptions differ to such an extent.

Valda Čakare ("Clichés of Theatrical Gesture in the Recent History of Latvian Theatre"), on the other hand, explores the recurrent elements of acting: clichés, or štamps (Latvian term, borrowed from Russian, and conceptualised in the system of Stanislavsky), meaning an artistic means of expression which has been used so often that it is felt to be hackneyed or cloying. She examines clichés of theatrical gesture in Latvian theatre of the $20^{\text {th }}$ century against a historical backdrop, from the theatre models of Ancient Greece to the "new drama" and Stanislavskian psychological-realistic acting. Čakare analyses the genetic mechanisms of clichés in character representation. She claims that frequently repeated gestures, or the actor's personal clichés make the audience see the actor in the first place, not the character. Examples from different productions of Rūdolfs Blaumanis's classical play "In Fire" (1905) demonstrate how the actors' physical expressions have been simplified to an extent that they have maximum communicative value, and become a condensation of emotions with stable meaning, in other words - clichés. Thus, in spite of the generally acknowledged transient character of theatre, especially acting, certain elements in it tend to demonstrate unexpected longevity - until their stability acquires pejorative connotations.

Another article concerned with the problems of acting is Eike Värk's "Effect of Tradition and Innovation on an Actor's Work Over Time: The Example of Salme Reek". This article observes the dialectical relationship of innovative and traditional impulses 
that influence the different roles created by an actor. The example of Estonian actress Salme Reek (1907-1996) is productive because of her exceptional longevity: her career in the theatre lasted over sixty years and progressed within changing social and cultural contexts and various artistic styles. Värk examines Salme Reek's work against the social-cultural background, and analyses the most important roles of the actress, demonstrating changes in her acting techniques. Nevertheless, alteration in acting is not discussed and valued only in a longer temporal frame, but also as the ability of the actor to transform and embody different characters during a short time-span. (It seems that such skill of re-impersonation is regarded very highly in small cultures, where the community of actors is limited.) But the versatility of the actor must also be supported by his or her ability to repeat a role's core many times, which is often considered to be one criterion of professionalism.

While Valda Čakare puts her emphasis on the stable if not petrified elements in acting techniques, Reetta Jokinen focuses on a particularly dynamic form of acting - improvisation theatre. In her article "Improvisation Theatre Performance as Maintaining and Breaking Cultural Model Narratives" Jokinen examines some possibilities of how improvisation theatre maintains culturally specific modes of narratives, and exemplifies this with the analysis of a theatre performance by Finnish Improvisation Theatre Joo. Thus, her argument is based on personal experience as an actor of improvisation theatre. She states that in improvised theatre performance, multiple different narratives are displayed simultaneously, and many possibilities of a plot co-exist together in every moment. Different narratives often comment on each other and point to other texts. What is performed on the stage is rather a complex mixture of influences, from the actors' unique personal narratives and their life experiences, particular group dynamics, and the cultural context where the work takes place. Improvised performances can be seen as representations of and reactions to modern culture, in which everything is changing quickly, and people are required to adapt to new situations. Nevertheless, the interplay of stability and dynamics can be detected even in such a dynamic theatre form as improvised theatre, where actors often tend to stick to familiar patterns of behaviour.

The next two articles concern themselves with postmodern aesthetics and destabilization of main means of performance art: text and body. Knut Ove Arntzen explores nomadic arts in the past and in the present, concentrating mainly on the performance activities of the Sami people in Norway, but also drawing parallels with similar events in other places. Further on, he elaborates on the term nomadism (as a notion of mobility associated with nomads) in new artistic and theatrical works: "Artists can be looked upon as mobile people, moving through different geographical areas to learn and to produce." Arntzen defines nomadic art in the metaphorical sense as a combination of traditional "art forms" (rituals, story-telling etc.) with elements of contemporary arts or intercultural projects where exploration of (personal, local, national etc.) identities dominates over artistic expression. In other words, the so-called postmodern tramp tries to unite indigenous traditions with an international language of 
arts; personal experiences with mythical or existential flows of life; constant physical and intellectual dynamics with traditional/local art forms or world views.

Jurgita Staniškytè investigates aesthetic changes that took place in Lithuanian theatre at the end of the 1980s and in the 1990s, labeling the new trends with the notion of postmodernism. Staniškyte finds that both the apprehension of the impossibility of innovation as well as the limits of theatrical means of representation in postmodern culture forced theatre makers to question the functions and means of performance arts. New directors attempted to mix the traditions of Lithuanian theater with new local trends and global tendencies, thus combining opposite poles of the scale "stability-dynamics" and of another scale "localglobal", creating the hybrid and peculiar Lithuanian performances. The main characteristics of "the local postmodernism" are referred to as self-reflexivity and the post-representational body, which are subjected to closer, more thorough analysis.

In the article "Building in the Daytime, Demolishing at Night" Jaak Rähesoo states that even though stability and dynamics obviously presuppose each other, these concepts assume greater importance in historically relativized contexts, when differences of emphasis come to the fore. He draws upon the one-hundred-year history of professional Estonian theatre to observe "fluctuations or cycles across the scale drawn by these two concepts". Relying on the metaphoric image of house-construction, Rähesoo shows how periods of building professional Estonian theatre (incl. buildings) on the solid ground of realism have alternated with periods dominated by the destructive power of modernism (destructive at least with respect to realism). Even though the development of Estonian culture has taken place mainly under the aegis of novelty and dynamics, the article also demonstrates the relativity of these terms. For example, in the Soviet Estonia, the restoration of pre-war aesthetic forms was considered an intermediate step towards more radical innovations.

In her article Anneli Saro reviews the dynamics of the Estonian theatre system, concentrating especially on the period from 1985 to the present. This period is known as a time of rapid political and economical transition, but these changes had relatively little influence on the theatre field. It is stated in the article that the Estonian theatre system has been transmitted from one historical period to another, first of all, by ideological valuation of traditions and stability, and only secondarily by firm institutions (incl. buildings) and a system in continuous operation. Nevertheless, several new private theatres that emerged in the end of 1980s and in the beginning of 1990s have changed the theatre field, exerting a slow but considerable influence on the organisation and aesthetics of old state theatres. Repertoire theatres have also copied several working principles from project-based theatres, which have been considered so far as the total opposite of the state-controlled repertoire theatre system. The article concludes that the surrounding cultural environment inevitably influences both the artistic and the organisational side of theatre.

This conviction also predominates in the article by Pirkko Koski, who investigates Finnish 
productions and reception of Shaw's plays - "Mrs. Warren's Profession" and "Widowers' Houses" - at the beginning of the $20^{\text {th }}$ century. The public performance of these "plays unpleasant" was banned by the English censorship but at the Folk Stage in Helsinki they had success both among critics and the larger public. The author of the article explains this fact by the various social and cultural contexts into which the plays were inserted. First, the sociopolitical situation and background of audiences in England and in Finland differed considerably at that time. Second, the Folk Stage had a reputation for staging mainly modern drama and innovative productions, which also justified the presentation of ideologically dangerous leftist topics. Third, in spite of the latter statement, the interpretations of the plays at the Folk Stage stressed more characters and melodramatic plot instead of metaphors, social criticism and irony, which was obviously the main intention of the writer. (Koski here makes an intriguing observation: "Halme's interest in the people is still also connected to the ideal education of the national ideology, to tradition.") Fourth, the strange location and characters created alienation and through this, a reassuring distance between the fictional world and spectators' social reality. The case study vividly demonstrates the dynamics of texts and topics in the (performance) arts: changes in spatial-temporal conditions cause major differences in the understanding and interpretation of a work, both among mediating artists and spectators.

The next three articles discuss the phenomenon of national theatre. Edgaras Klivis takes as his focus the establishment of Lithuanian nation and national theatre in foreign industrial centers at the turn of the $20^{\text {th }}$ century. There are two main sources under consideration: "Lithuanian Theatre in St. Petersburg 1892-1918" by Balys Sruoga (published in 1930) and a general Lithuanian theatre history by Vytautas Maknys (published in 1972). Although the works are written in different historical periods, they demonstrate obvious ideological similarities in dealing with this early period of Lithuanian theatre. The central notions used in defining national culture are the metaphysical idea of homogeneous origins/roots, which seems to be common to nationalist historiographies also in other countries. Klivis states that this point of view is a response to the political circumstances of the historical periods, but we can elaborate the argument further, taking into consideration a wide time span and a broad political spectrum, and come to the conclusion that ideologies of national culture tend to be quite stable, in spite of political changes. First, relying on Ernest Gellner, Klivis demonstrates how the mediation and the heterogeneity of industrial society determine the formation of national culture and national theatre at the Fin de Siècle. But implicitly he finds that the situation is quite similar in the 1920s and 1970s when the aforementioned theatre historiographies were written - "thus in both of these cases, the history of theatre was being written in the face of issues of hybridization and heterogeneity". And these are issues Steve Wilmer will also tackle in discussing functions of National Theatres in the contemporary European cultural scene.

Explorations in the discourses of theatre historiography are also carried out in the article "Theatre in a Contorted Mirror of Satire: Lithuanian Example from 1924-1940" by 
Martynas Petrikas. The author takes two interwar satirical periodicals as empirical material to investigate how "myths" about theatre propagated by official discourse (theatre criticism, educational system etc.) were attacked by "counter-mythology" of satirical discourse. These aspects have mostly been ignored by theatre historiography. The official discourse was built on the image of theatre as a "temple of art and science", according to which theatre-going was considered to be a patriotic act supporting Lithuanian culture. Satirical publications, on the other hand, depicted theatre (both institution and art form) as a site of corruption, immorality, and waste of state subsidies. In principle, this point of view has also found many supporters in other times and places, but nowadays officially "silenced voices" can easily find expression in different internet forums, which are overlooked by theatre historians. But these alternative sources will certainly destabilize or enrich hegemonic attitudes and stereotypes about theatre, and might even lead to redefinition of the art form that Willmar Sauter demonstrated in the first article of this volume.

Steve Wilmer investigates functions and ideological principles of European national theatres throughout history. Every National Theatre carries some unique qualities, and certain patterns of similarities can be detected among them. The National Theatres that were created in the late $18^{\text {th }}$ to the early $20^{\text {th }}$ century (either by autocratic rulers or citizens-activists!) played a crucial role in national identity building, where staging authentic plays about local history or heroes and speaking colloquial language on stage were main strategies. Wilmer states that even today many notions of national identity still owe their origins to nineteenth-century myth-making by cultural nationalists, even though they relied on essentialist and exclusionary ideology of identity. But functions of the National Theatres started to change in the $20^{\text {th }}$ century, together with the disappearance of empires, establishment of nation-states, increasing multiculturalism and globalization. Nowadays the National Theatres, in spite of continuous proliferation, need to legitimize their institutional status and sizeable state subsidies because the notion of homogeneous national identity has been exposed by multi-lingual and poly-ethnic populations, international co-operation, multilingual performances and international touring. It comes to the fore from the article that though the economical, political and cultural climate in Europe has gone through a process of homogenization, the National Theatres have reacted to the changes quite differently in their search for new functions and identity.

What have we learned from this diverse selection of case studies? At least since the $19^{\text {th }}$ century with the rise of national feelings and nation-states, industrialisation and later modernism, cultural dynamics has been valued over stability. However, following the recommendations of German romantics, cultural evolution was at least partly established through "roots" of old folk culture, which tends to be rather inert. The same pattern can also be recognised through the $20^{\text {th }}$ century: in the framework of international cultural trends, some elements of local traditions have always been saved and integrated into new forms of 
art. Contrary to most commodities, art systems which are bound to local contexts favour and generate more diversity both in production and reception. Discourse of art is clearly concentrated on diversity and dynamics; stability is rather seldom investigated and valued. In the field of theatre research, Marin Carlson's book "The Haunted Stage" (2001) deserves special mention in this context. Although culture itself is mostly based on traditions and continuity - and this applies also to theatre, as Carlson has convincingly demonstrated -, at the core of modern arts there exists a strong urge for constant alteration and opposition. And this is definitely the phenomenological spirit of the ephemeral art of theatre.

\section{References}

Carlson, Marvin 2001. The Haunted Stage: The Theatre as Memory Machine. Ann Arbor: The University of Michigan Press.

Fischer-Lichte, Erika 2001. Ästhetische Erfahrung: Das Semiotische und das Performative. Tübingen, Basel: A. Francke Verlag.

Genette, Gérard 1994. L' Oeuvre de l'art: immanence et transcendance. Paris: Éditions du Seuil.

Lotman, Juri 1999. Semiosfäärist. - Semiosfäärist. Tallinn: Vagabund, pp. 7-35.

Lotman, Juri 2001. Kultuur ja plahvatus. Tallinn: Varrak.

Postlewait, Thomas 1991. Historiography and the Theatrical Event. A Primer with Twelve Cruxes. - Theatre Journal, Vol. 43, No. 2, pp. 157-178.

Väljataga, Märt 2008. Narratiiv. - Keel ja Kirjandus, No. 8-9, pp. 684-697.

Woods, Alan 1989. Emphasizing the Avant-Garde: An Exploration in Theatre History. - Interpreting the Theatrical Past: Historiography of Performance. Eds. Thomas Postlewait, Bruce McConachie. lowa: lowa University Press, pp. 166-176.

Zarrilli, Phillip B., Bruce McConachie, Gary Jay Williams, Carol Fisher Sorgenfrei 2006. Theatre Histories: An Introduction. New York, London: Routledge.

Luule Epner - is a Senior Researcher at the Institute of Cultural Research and Fine Arts of the University of Tartu (Estonia). Her main research fields are history of Estonian theatre, relationships of drama text and theatre performance, performance analysis. She has published a book about drama theory Draamateooria probleeme I-II $(1992,1994)$ and is a co-author of a monograph about Estonian literary history (Eesti kirjandus/ugu, 2001).

E-mail: luule.epner@ut.ee

Anneli Saro - is an Associate Professor of Theatre Research at the University of Tartu (Estonia). She has published articles on audience research, performance analysis and Estonian theatre history. Currently she is studying Estonian theatre systems in the working group "Project on European Theatre Systems" and is a member of the executive committee of the International Federation for Theatre Research.

E-mail: Anneli.Saro@ut.ee 


\section{Teater: stabiilsus ja dünaamika}

Luule Epner, Anneli Saro

Käesoleva numbri teemat piiritlevad mõisted stabiilsus ja dünaamika ei ole antonüümid, s.t ei moodusta selget binaarset opositsiooni ega dihhotoomiat, ja teiseks, mõlema mõiste konnotatsioonid on positiivsed, mida ei saa niisama kindlalt väita nende otseste vastandite - labiilsuse ja staatika - kohta. Stabiilsus, mis lähtub ladina keelest (stabilis 'kindlalt seisev, kõikumatu') tähendab süsteemi või nähtuse püsikindlat olekut ning näitab tagasisidestatud süsteemide talitlusvõimelisust. Süsteemis tegutsevatele inimestele annab stabiilsus turvatunde, mis on inimese oluline emotsionaalne vajadus. Ent niisama vajalik ja väärtustatud on dünaamika (kreeka dynamikos 'jõusse puutuv, jõu-'), mis tähendab süsteemi või nähtuse muutumist, arenemiskäiku. Tänu niisugusele positiivsele tähendussisule tunduvad stabiilsus ja dünaamika olevat head katusmõisted, mille varal on võimalik käsitleda eritasandilisi suhteid nii teatriajaloos kui ka etenduse analüüsis.

Sündmusi seostades ja järjestades, s.t narratiive konstrueerides tunneb teatriloolane tavaliselt ikka huvi selle vastu, mis on muutunud, millised arengud on aset leidnud, mis on neid põhjustanud jne. Kui vaadelda teatriajalugu muutumise prisma läbi, siis tuleb mängu terve rida kategooriaid ja mõisteid, mille abil ajaloolisi protsesse on võimalik modelleerida: progress, uuendus, revolutsioon, murrang, kriis, tsüklilisus, katkestus, transformatsioon jne. Mis liiki ajalugu kirjutatakse, sõltub sellest, milliseid mudeleid eelistatakse ja väärtustatakse. Teatriajaloo uurimises on pendel liikunud uuenduse ja traditsiooni pooluste ehk dünaamika ja stabiilsuse rõhutamise vahel.

Nimetatud mõistepaar kirjeldab olulisi aspekte ka teatri ontoloogias. Teatri spetsiifiliseks omaduseks peetakse etenduse kui teatrikunsti teose ainukordsust ja ebapüsivust, millega seostub dünaamika mõiste. Ent kaduvuse-ülistusega rööbiti eksisteerib iha teatrietendust ikkagi korrata ja jäädvustada, päästmaks teda mitte-olemisse ja unustusse vajumast, ning sellega seostub stabiilsuse mõiste. Performatiivne pööre on toonud püsivuse ja muutumise dialektika selgemalt ka etenduse analüüsi ja retseptsiooniuuringute diskursusse. Lineaarsete ja/või dihhotoomiliste kirjeldusmudelite taandumist niisuguste mudelite ees, mis käsitlevad protsesse ja nähtusi pidevate spektrite ja kontiinumite kaudu, võibki pidada tänapäeva teatriuurimise üldiseks epistemoloogiliseks raamistikuks.

Lu ule Epner - teatriteaduse vanemteadur Tartu Ülikooli kultuuriteaduste ja kunstide instituudis. Peamised uurimisvaldkonnad: eesti teatri ajalugu, draamateksti ja teatrietenduse suhe, etenduse analüüs. Avaldanud raamatu „Draamateooria probleeme” I-II (1992, 1994). „Eesti kirjandus/oo” (2001) üks autoreid.

E-post: Luule.Epner@ut.ee

Anneli Saro - teatriteaduse dotsent, Tartu Ülikool (Eesti). Ta on avaldanud artikleid publiku-uuringute, etenduse analüüsi ja eesti teatri ajaloo teemadel. Praegu tegeleb ta Eesti teatrisüsteemide uurimisega töörühmas „Project on European Theatre Systems" ning on Rahvusvahelise Teatriuurimise Föderatsiooni täitevkomitee liige.

E-post:Anneli.Saro@ut.ee 